\title{
The Responsibility to Protect, the Right to Assist and the Right to Resist
}

Craig S. Brown ${ }^{1}$

\section{Abstract}

The Responsibility to Protect (RtoP) has come under heavy criticism following its invocation during the 2011 intervention in the Libyan conflict. The perceived unworkability of RtoP for future intervention to prevent atrocity crimes has formed the basis of continued development of the concept of the 'right to assist', which has emerged in the nonviolence literature as a means of responding to the needs and requests of individuals engaged in campaigns of nonviolent resistance. Although couched in the language of a need to respect bottom-up actors engaged in nonviolent resistance, the nonviolence literature from which RtoA has emerged indicates reasons to be cautious. Drawing on the developing critical nonviolent resistance literature, this study suggests that efforts to discipline and restrict resistance to nonviolent forms of conflict, and indeed to limit conflict to the terms established by external actors, seem to inherently afflict the concept of RtoA.

Keywords: Responsibility to Protect, right to assist, human security, nonviolence, nonviolent resistance

1 Craig S. Brown received his PhD from Leeds Beckett University. He is currently an Assistant Editor and Book Review Editor for the Journal of Resistance Studies, as well as a Board Member for the European Peace Research Association.E-mail:craigsbrown1987@ gmail.com. 


\section{The Responsibility to Protect, the Right to Assist and the Right to Resist}

\section{Introduction}

Following the 2011 intervention in the Libyan conflict under the Responsibility to Protect (RtoP), significant questions over RtoP's future workability have been raised. Within the nonviolence literature, one means of continuing the practical adoption of intervention as a means of avoiding 'atrocity crimes' has been the 'right to assist' (RtoA) nonviolent campaigns of civil resistance. RtoA's formulation predated NATO's Libya military intervention, although the campaign's dubious outcomes would seem to make the question over preventative strategies, such as RtoA, reasonable and rational to pursue. However, the assessment here is that, fundamentally, the premise of RtoA has thus far failed to escape the established criticism of RtoP and military intervention.

This paper first introduces the concept of RtoA, then situates it in relation to RtoP. It is apparent that at least on a theoretical or ideational basis, RtoA offers little that is new in its focus on prevention. This is because of the established acknowledgment in UN documents of the need for preventative action short of military intervention, as well as a requirement for action below that mandated by the UN down to individuals.

Subsequently, RtoA is placed in the context of the broader field of nonviolence, both in terms of the literature shaping the concept and the literature that may be applied in critique of RtoA's fundamental underpinnings. The former literature is that relating to quantitative, 'pragmatic-strategic' inquiry into nonviolence, which has resulted in an emphasis on key civil resistance variables such as nonviolent discipline. The latter literature is that 
concerned with the critical nonviolent resistance field, which broadly perceives some of the former pragmaticstrategic literature as serving a disciplining function. Through introducing the critical resistance literature, this study contributes to exploring the suggestion that human security should be reformulated as a resistance strategy (Martin, 2017: 24; Chinkin \& Kaldor, 2017).

A further issue is raised relating to the concept of the civilian, which given the ongoing erosion in the boundaries between combatant and non-combatant in contemporary conflict is an important concern during both violent and nonviolent conflict. The conflation of 'civilian' with civilian resistance in certain areas of the nonviolent literature stands to further compound this erosion, particularly in the context of the increasing significance of complex modes of conflict that merge the boundaries of violent and nonviolent action, for example so-called 'hybrid warfare'. Some form of expansion of the application and coverage of 'civilian' may remove genuine popular resistance from the sphere of military manipulation and render participants some protection under RtoP. Nevertheless, the notion of 'civilian resistance' continues to pose troubling questions about RtoA and associated nonviolent dynamics' disciplining function.

\section{'Right to Assist'}

Over a decade ago, Ackerman and Rodal posited the 'right to help'-latterly the 'right to assist' in Ackerman and Merriman's (2019) parlance-as a right of external, cross-border support to be afforded in response to "the needs and requests for help of people denied universally accepted rights" (2008: 122). Given that I am considering some of RtoA's ambiguities, before embarking on a critique of the concept it is important to note that Ackerman and Rodal evidently do not question a 'right to resist' (2008: $112,115)$, although they do believe that resistance which RtoA is relevant to should be nonviolent (Ackerman \& Merriman, 2019: 20-22). Moreover, Ackerman and Rodal (2008: 122) and Ackerman and Merriman (2019: 
22-23, 32) stress that RtoA should not be considered a strategy for interference or top-down, external control as indigenous, bottom-up civil resistance strategies should be respected. While not suggesting these positions are disingenuous, there are limitations and caveats posed on 'legitimacy' and capacity of nonviolent resisters through RtoA in terms of a reasonable right to resist oppression, which may be inherent in the move towards legalisation and enshrining of assistance in a right. The most obvious response would be that acknowledging RtoA would not remove the right to resist outside the parameters of strict nonviolence. However, Ackerman and Merriman's (2019) assessment of the action permissible under RtoP seems quite restrictive itself, while the ultimate question is why assistance needs to be a right, given that informal action has always been undertaken in support of nonviolent resistance campaigns. If an authoritarian regime refuses this right, presumably that refusal places them in further transgression of 'human security' paradigms and IHRL, thus eventually risking military intervention.

It is important to note that RtoP's remit is limited to the prevention of 'atrocity crimes', even if the action that the UN has outlined that may be taken to prevent such crimes is broad. Therefore, RtoA must be seen within this limited remit. Ackerman and Merriman acknowledge that the prevention of atrocity crimes is "an important exception to the principle of non-intervention", which nevertheless depends on the UN Security Council, meaning that intervention can simply be vetoed (2019: iii, 2). They also argue that the 2011 armed intervention against Muammar Gaddafi in Libya under RtoP ultimately "resulted in significant loss of life. It did not stop violent conflict while Qaddafi remained in power, and it led to further violent conflict and regional instability after Qaddafi's ouster" (2019: 2). Accordingly, Ackerman and Merriman posit RtoA as a crucial component of preventing the risk of atrocities through strengthening:

international coordination and support for nonviolent civil resistance campaigns demanding rights, freedom and justice against non-democratic rule. RtoA would: 1. engage a wide range of stakeholders such as NGOs, states, multilateral institutions and others; 2 . bolster 


\section{European Human \\ Journal of Security}

various factors of resilience against state fragility; and 3. incentivise opposition groups to sustain commitment to nonviolent strategies of change (2019: iii).

Although RtoA in relation to the specific character of nonviolence during campaigns is significant to discuss, it is worth considering RtoA's impetus - as a form of intervention that is short of armed coercion, with a significant non-state component and an emphasis on prevention-in relation to the present understanding of RtoP.

\section{Right to Assist in the Context of the Responsibility to Protect}

Although Ackerman and Merriman (2019) focus on the significance of activity pertaining to pillar two of RtoP-international assistance and capacity rebuilding-and an emphasis on prevention over armed intervention, it is not apparent that the UN overlook such efforts, nor that the UN have purely focused on state action and responsibility. An emphasis on prevention appears in various significant documents relating to the UN's clarification of RtoP (United Nations General Assembly, 2009: 7; United Nations General Assembly \& United Nations Security Council, 2011: 5). More significantly, prevention is linked to different sub-state activity, including the moral responsibility of individuals to protect: "those who refuse to look away or to participate, who shelter the vulnerable, and who speak out against the dehumanization of the targeted groups and for human rights and human dignity are exercising individual responsibility" (United Nations General Assembly \& United Nations Security Council, 2011: 4). Such actions are considered as building societies resilient to violence and atrocity crimes generally, not just during armed conflict (United Nations General Assembly \& United Nations Security Council, 2013: 3-4). Furthermore, the need for external assistance to be mindful of specific contexts and grassroots action has been acknowledged by the UN: 


\section{European Human \\ Journal of Security}

Bottom-up learning processes can provide essential lessons with regard to the methods of self-protection that have been developed and practiced at the village and even family levels in places of recurring violence and repression. These complement the emphasis, within the framework of the responsibility to protect, on prevention and helping the State to succeed, instead of reacting once it has failed to protect. Training, education and awareness-raising are natural areas for new regional initiatives and global-regional-national partnerships (United Nations General Assembly \& United Nations Security Council, 2011: 5; 2012: 2).

Crucial here is that such sub-state initiatives evidently do not require a UN mandate or UN Security Council assent, which is Ackerman and Merriman's (2019) main issue with the workability of RtoP. While such efforts to avoid violence and ultimately atrocity crimes may be organised and undertaken in cooperation with the UN, for example in the case of Nonviolent Peaceforce (see United Nations General Assembly \& United Nations Security Council, 2015), throughout history such actions challenging the worst instances of human behaviour have been individual, 'spontaneous' and by no means according with legal 'permissibility' (see Sémelin et al., 2011). This is especially the case when such atrocities actually have a legal foundation and resistance to them is illegal (United States Holocaust Memorial Museum, 2019a, 2019b).

Clearly, such cases of legal atrocity differ from the legal protection that is sought through international law precisely to avoid atrocity crimes, although where this leaves RtoA is intriguing. What does and indeed can RtoA contribute, particularly in circumstances where international law stipulates that prevention is necessary, where RtoA seeks nonviolent intervention, yet states where this assistance is provided are likely to consider it illegal and an infringement of sovereignty? Ultimately, it seems to be the case that the UN's formulation of RtoP approves of preventative action without UN assent; a right to nonviolently assist nonviolent resistance campaigns would only legally enshrine this assistance 
yet, given Ackerman and Merriman's (2019) criticism of armed intervention, provide no more robust measures in response to a state claiming interference than measures short of armed intervention (United Nations General Assembly \& United Nations Security Council, 2012: 9) to hypothetically enforce the right to protest for civil and political rights under the International Covenant on Civil and Political Rights (1966) - a right Ackerman and Merriman believe is afforded greater protection than RtoA (2019: 27-28).

To my mind, when one thinks through these ambiguous legal implications and contributions of RtoA, one has to consider what precisely Ackerman and Merriman (2019) want to contribute through their conception of RtoA. This seems to make the issue of nonviolence and nonviolent resistance campaigns essential, with two main aspects to Ackerman and Merriman's position. First is civil resistance's superior capacity to avert civil war and the prospects of atrocity crimes compared to civil war and violent conflict (2019: 25-26). Second is the right to assist civil resistance campaigns as a way of strengthening capacity to avoid a descent into violent conflict, hence the risk of atrocity crimes (2019: 9). Ackerman and Merriman stipulate three baseline criteria for a campaign to receive assistance: "a. A campaign is committed to nonviolent discipline [...] b. A campaign's goals are consistent with internationally recognised human rights [...] c. The civil resistance campaign is separate from a registered political party" (2019: 2022). As mentioned above, it is important to note that Ackerman and Merriman acknowledge the impracticality of a campaign guaranteeing nonviolence, the importance of context-specific circumstances (2019: 20-21), as well as the potential problems of external assistance such as delegitimising of a campaign (2019: 23-24). Ultimately, the significance of listening to and respecting local actors is emphasised (2019: 23-24). While this is positive to stress, certain indicators in Ackerman and Merriman's proposal, seen in the context of recent research on nonviolence which has been of a quantitative nature and 


\section{European Human \\ Journal of Security}

Page I 12 of conflict. This is indicated by some of the 'concerns' Ackerman and Merriman acknowledge and thus the intended audience, for example 'concern two': "is support for civil resistance synonymous with supporting regime change?" (2019: 22-23), as well as 'concern four': "What if external support contributes to societal instability?" (2019: 25). Responding to the latter, the researchers (2019: 26) rather tellingly quote the third sentence from this excerpt from Stephan et al. below (the full paragraph being even more revealing):

External actors must come to terms with the fact that progress in consolidating democracy may not always be linear and that civic actors may choose to engage in nonviolent, extra-institutional tactics to advance social and political change. However, the popular movements in the Middle East and North Africa have shown that we cannot assume that such movements immediately lead to clear social or political outcomes, stability, or the kinds of political systems and leaders desirable to our governments. Because outside actors probably will not be able to prevent people from engaging in protests or other direct action [emphasis added], particularly if they are suffering acute grievances, to minimize risk of violent instability they could invest in helping civil societies develop the capacity to organize nonviolently and maintain nonviolent discipline (2015: 11; see also Ackerman \& Rodal, 2008: 122-123).

Thus, as well as prevention of nonviolent conflict being suggested as desirable yet unfeasible and nonviolent conflict ideally being prosecuted in the USA's interest (in this example), Stephan et al.'s paper seems to posit nonviolence as one indicator of who among diverse, networked and informal civil society actors may be identified as suitable for external donors to support (2015: 
4-7; see also Chenoweth \& Stephan, 2011: 27). This of course makes the nonviolent discipline of such actors important to those donors as a quantifiable and reportable variable, rather than being necessary at a practical level.

\section{RtoA in the Context of the Broader Nonviolent Literature}

13 I Page

Exploring this question of practical necessity further, it is first worth observing that the attempt to mitigate the unpredictability of conflict through the emphasis on nonviolent discipline has been joined with arguments for the superior prospects of nonviolent discipline in terms of resistance campaigns' success. Particularly over the previous decade, a notable trend in nonviolence research has been study of large- $\mathrm{N}$ datasets, particularly the Nonviolent and Violent Campaigns and Outcomes (NAVCO) datasets. Chenoweth and Cunningham (2013) suggested that with studies such as those by Schock (2005), Stephan and Chenoweth (2008), Shaykhutdinov (2010), Svensson and Lindgren (2010, 2011), Nepstad (2011) and Chenoweth and Stephan (2011), civil resistance research has taken a more "empirical and analytical perspective" (Chenoweth \& Cunningham, 2013: 272; Nepstad, 2013: 592; Gleditsch et al., 2017: 268). A quantitative empirical approach, developing hypotheses and testing theory based on the available literature, has become a common trend in this regard (see Chenoweth \& Schock, 2015; Bayer et al., 2016; Butcher \& Svensson, 2016), with large-N studies also more prominent (Stephan \& Chenoweth, 2008; Chenoweth \& Stephan 2011; Asal et al., 2013; Chenoweth \& Lewis, 2013; Cunningham, 2013; Koren, 2014; Sutton et al., 2014; Chenoweth \& Ulfelder, 2015; Hegre et al., 2017; Gleditsch et al., 2017: 268; see also Schock, 2013: 286-287). A major finding was offered by Stephan and Chenoweth when they determined that 26 percent of violent resistance campaigns could be considered successful, compared to 53 percent of nonviolent ones (2008: 8; see also Chenoweth \& Stephan, 2011: 6-7). 


\section{European Human \\ Journal of Security}

Page I 14

Accordingly, there has been greater focus on identifying variables such as nonviolent discipline that increase the prospects of success (Stephan, 2009a; Bamyeh, 2012: 56; Davies, 2014: 310; Ettang, 2014: 418; Khatib \& Lust, 2014: 9), and research showing the disadvantages of violent 'flanks' (Schock, 2013: 282; Chenoweth \& Stephan, 2011: 202; Schock, 2015a: 1314; Schock, 2015b: 310; Hallward \& Norman, 2015b: 24; Chenoweth \& Schock, 2015: 446-447). Stephan's (2009a) edited volume considered cases of nonviolent resistance in the West Asia-North Africa (WANA) region prior to the 2010/11 WANA revolutions, indicating the importance of three general "ingredients" that "may not be sufficient to guarantee success, though without all three it is unlikely that a nonviolent campaign will succeed [...] unity, strategic planning, and nonviolent discipline" (Stephan, 2009b: 311). The commitment to nonviolent discipline has subsequently been emphasised as essential during the 2010/11 WANA revolutions (Boesak, 2011: 4; Bamyeh, 2012: 56; Ettang, 2014: 418; Khatib \& Lust, 2014: 9).

However, the emphasis on statistically proving nonviolence's effectiveness may contribute to the instrumentalising of nonviolence, particularly in producing a set of outcome variables under the common heading of 'democratisation' (Ackerman \& Kruegler, 1994: 10-11; Stephan, 2009a: 3; Sharp, 2010: 2; Chenoweth \& Lewis, 2013; Bayer et al., 2016: 758, 761), which is typically of a particular liberal democratic and neoliberal economic bent (Chabot \& Sharifi, 2013: 18; Honwana, 2013: 91). A further aspect is that, as with Chenoweth and Stephan's (2011: 208) assessment, democratisation is clearly intended to be an institutionalised process, with nonviolent movements being seen as "credible negotiating partners" (2011: 11) and democratic transitions "driven by an interactive process involving elites and grassroots civic elements" (2011: 204). While Chenoweth and Stephan make an important qualification - "there is no such thing as a one-size-fits-all democratic structure" - they ignore this and proceed to use "the standard description in political 
science" of electoral and rights-based liberal democracy (2011: 202-203). Garton Ash suggested that defining success as "to achieve consolidated liberal democracy" is acceptable, "so long as we are explicit about the nature of the exercise" because, "we are measuring achievement and outcomes ex post facto, by standards that seem to us valuable" (2009: 389-390). Regardless, this overlooks the power inherent within this exercise, as there remains a case of universalising what is valuable to 'us'-the minority world (see Jackson, 2015: 20-21).

With such research providing the basis of RtoA's development, evidently there is nothing problematic about expanding into a further research area for exploring nonviolent and violent resistance through producing large-N studies (Chenoweth \& Stephan, 2011: 17). Nevertheless, certain disconcerting trends are continuing in quantitative assessments. Chenoweth and Ulfelder expressed the conviction that "mass episodes of nonviolent resistance" can be both predicted and generalised in terms of trends and characteristics (2015:2), although they believed that existing conflict analysis and structural theories are ineffective for explaining their "complex systems dynamics" (2015: 21; see also Hoynes, 2014: 1-2). First, one may ask who generalisation and prediction benefit; Jackson suggested there is a real question over whether the aim of such civil resistance research is "normatively motivated by social justice", or seeks to "furnish the authorities with greater knowledge for the purposes of deterring, preventing, suppressing or punishing nonviolent resistance movements which challenge the status quo" (2015: 20). I believe this question is partially resolved in favour of the latter position by my own analysis of how the WANA revolutions have been framed and the deeper change sought overlooked, replicating structural forms of oppression (Brown, 2016; Brown, 2019: 26-30).

Regarding the practical implications of RtoA's push for nonviolent discipline, such discipline has been considered crucial because even minor violence can undermine nonviolent action's dynamics while justifying heavy repression (Davies, 2014; King, 2009) While this is 


\section{European Human \\ Journal of Security}

Page I 16

convincing, my own research into the 2010/11 Tunisian revolution found that in the Tunisian context nonviolent discipline was not a particularly overriding concern, nor ultimately a necessary one. Protester violence in the specific context of Tunisia was accommodated and rationalised in stark contrast to the regime's violence by most Tunisians who I interviewed, including in selfdefence, largely taking the form of destruction of state infrastructure and stone throwing, but also attacks on and in one rare instance of killing a policeman rationalised by one interviewee (Brown, 2018; Brown, 2019: 132, 201202). During the 2011 Egyptian revolution, instances of stone throwing and other protester violence have been suggested as having undermined nonviolence (Davies, 2014: 310), although protester violence has been suggested as being significant during the Egyptian revolution (Case, 2018). It should be noted further that even in instances where the quantity of violence in a campaign is limited, it may have been crucial in certain instances, for example in the defence of Tahrir Square as an emancipated space during the 'Battle of the Camel' on February 2 ${ }^{\text {nd }}, 2011$ (Basu, 2012; Bilgic, 2015: 280).

Although this does not reduce the significant role that nonviolence played and the broadly nonviolent nature of Tunisia and Egypt's revolutions, considerations regarding violence will be context-specific (see Brown 2018, 2019: 310-313; Reed \& Foran, 2002: 339-340; Chabot \& Vinthagen, 2007: 94). This reflects the acknowledgement in some of the more recent resistance literature (Vinthagen, 2015a; Baaz et al., 2018) via Naess (1974) that actions will often be context-specific in their effectiveness, including nonviolent action (Vinthagen, 2015a: 91). Indeed, there is some acknowledgement of the need for strategic and tactical creativity, flexibility and consideration of the specific context for the nonviolent movement and its actors among nonviolence's 'pragmatic-strategic' advocates (Ackerman \& Kruegler, 1994: 29, 35, 46-47, 51; Chenoweth \& Stephan, 2011: 221; Pearlman, 2011: 9; Bartkowski, 2015: 150; Schock, 2015a: 16). Nevertheless, there appears to be an emphasis on strong-arming evidence for universally appli- 
cable strategic principles derived from (but not necessarily reflecting) Gene Sharp's work that have been successfully transferred and applied across countries via 'strategic learning' (Ackerman \& Rodal, 2008: 117). Sørensen's (2017) rigorous critique of Ackerman and Kruegler's case study of Danish resistance to the German occupation during World War Two conveys their overlooking of caseand context-specific complexity. Her damning implication is that "for an applied field such as civil resistance, flaws in theories and models can have consequences for ongoing and future struggles", including the endangering of participants lives (2017: 132). Of further significance is that Lehoucq (2016) has suggested flaws in Stephan and Chenoweth's (2008: 8) statistical data that skews the success rate of nonviolence (Lehoucq, 2016: 277-279, 284). The implications of this require serious contending with, albeit outside of this paper's focus (see Brown, 2019: 284); while not disproving the effectiveness of nonviolence, it conveys further the problem of quantification and the identification of certain variables for effectiveness and success, which evidently has implications for RtoA.

One qualification is that regardless of RtoA rhetoric regarding indigenous, grassroots dynamics, the external pressure to be nonviolent simply to receive assistance could override what seems tactically or strategically necessary on the ground in certain contexts. A 'fullspectrum' (non)violent campaign may have popular legitimacy and support and-regardless of whether this is workable in the specific context in terms of establishing durable social change and reducing violence over the long-term-shifting to pursue nonviolent discipline to accord with external requirements is, at the very least, an inherent external 'direction' of a campaign potentially at odds with reaction to developments on the ground.

Seeking to summarise the discussion so far, there is clearly a broad scope of action short of armed, military, violent intervention, in the same way there is clearly a broad scope of conflict and its outcomes short of the most heinous excesses. Of course, atrocity crimes must be prevented; there are also individuals such as myself 


\section{European Human}

who would subscribe to the belief that any death during conflict is lamentable and should be avoided, and that nonviolent methods, particularly strategies inclusive of constructive resistance (see Sørensen, 2016), are the most effective way of building more equitable communities, respectful of rights and dignity and engaging in the nonviolent waging of conflicts. However, this is different to enforcing nonviolent discipline as requisite. This makes RtoA not simply another tool, or string to the bow of avoiding atrocity crimes, but seeks to mould the space of permissible conflict.

\section{RtoA and the Critical Nonviolent Resistance Literature}

Mindful of the longer quote from Stephan et al.'s paper above regarding the prevention of conflict and the influencing of change (2015: 11), such moulding can be clarified in the context of the emerging critique within the critical nonviolence literature. In this regard, resistance has been characterised as:

Processes of social change, different forms of resistance (everyday and organised) and violence (political and domestic) entangle and emerge as reactions to each other. Various resisting or violent practices constitute reactions or 'bi-products' of other practices, which thereby drive or provoke social change (Baaz et al., 2018: 7, 100).

With an emphasis on nonviolent resistance, the Journal of Resistance Studies exemplifies this developing strand (see Vinthagen, 2015c), which is linked to critical theory and Foucauldian theories' application to peace research (Patomäki, 1997a, 2001; Jackson, 2015), considering power, neoliberalism and resistance in a manner which Jackson suggests has typically been overlooked (2015: 31-37). Vinthagen (2015c) emphasised the importance of Foucault's ideas of power and resistance (2015c: 7), while Galtung's research is also drawn on to inform violence, resistance and power's interplay (Baaz et al., 2018: 102-103; Jackson, 2015: 31; Vinthagen 2015a: 65). This especially concerns 


\section{European Human}

direct, structural and cultural violence (Galtung, 1969; 1990: 292), alongside negative and positive peace, with the latter's focus on constructive activities.

One aspect of this critique relates to Jackson's suggestion that peace studies has generally perpetuated a Eurocentric, 'western' and top-down position that "violent conflict and injustice require 'peace', 'conflict management', and forms of liberal interventionism from external actors", typically "at the expense of social justice and local actors" (2015: 18; Clark, 2009: 2; Norman, 2015: 43-44; Vinthagen, 2015b: 262). There is of course an array of means through which nonviolent movements may receive and indeed request assistance (see Roberts, 2009: 18), not all malignant or concerning financing (Johansen, 2009; Dudouet, 2015: 169, 172-173; Julian \& Schweitzer, 2015: 3), with an authentic acknowledgement of the requirement to respect local actors, institutions and culture being expressed (Dudouet, 2015: 171; Julian \& Schweitzer, 2015: 3). A need for the peace research and nonviolence field to genuinely grapple with the implications of this seems to have been rejuvenated with a focus on resistance (Jackson, 2015: 18; Vinthagen, 2015c; Baaz et al., 2018), reflecting "the radical origin of peace studies and their commitment to emancipation" (Sørensen \& Johansen, 2016: 84), as well as questions of critical theory's place in the peace field raised over two decades ago (Patomäki, 1997a; 2001; Jackson, 2015). Jackson suggested this calls for a reorientation towards "local agency and priorities, local and everyday forms of peace, the role of power dynamics in conflict and peace, structural violence, solidarity, antiviolence and social justice" (2015: 18), while "de-privileging the field's position, empowering the other, abandoning Eurocentrism and putting immanent critique, radical activism and otherled research methodologies at the centre of its practices" (Jackson, 2015: 18; Norman, 2015: 48-51; Sørensen \& Johansen, 2016: 84; Baaz et al., 2018: 191-192).

For this critique of RtoA, it is worth situating such challenges to the established peace field in the context of 'risk', which has an established place in critical analyses of RtoP. First, although Ackerman and Merriman note that 


\section{European Human}

Page I 20

conflict is inevitable (2019: 34), 'violence' and 'conflict' are often conflated, both by researchers and international institutions, creating an assumption that all conflicts are objectionable and create detrimental outcomes, which has been roundly critiqued (see Sørensen \& Johansen, 2016: 86-87; Sharp, 1973: 8; Rogers \& Ramsbotham, 1999: 751; Jackson, 2015: 20; War Resisters' International 2017). Second, reflecting Beck's assessment of the identification and mitigation of "hazards and insecurities" as risk stemming from modernisation and globalisation (1992: 21, 29, 36; Bauman, 1997: 192-193), the development of the human security paradigm shifted the emphasis on territorial security to, as the International Commission on Intervention and State Sovereignty explained, "the security of people against threats to life, health, livelihood, personal safety and human dignity" (2001: 15). The Commission proposed that RtoP lies with the "state concerned", unless it is "unable or unwilling to fulfil this responsibility" (2001: 17), while emphasising the 'responsibility to prevent', necessitating effective early warning and predictive capabilities (2001: xi). Duffield identified human security as a "biopolitical category", concerning the "more diffuse and multiform threat associated with alienation, breakdown and insurgency emanating from the nominal populations of Southern states", and, "the ability of the people of former protectorates and colonies to enjoy complete and fulfilled lives" (2007: 112). Rather than human security's concern with violence and questions posed by sovereign power and responsibility, extending RtoP to nonviolent action in the manner advocated through RtoA risks transgressing the reasonable 'right to rebel' among populations and to action against a sovereign power. It appears that instability and risk per se is what is being regulated, and this once again suggests that campaigns' adherence to supposedly measurable nonviolent variables would expedite the prediction and control of nonviolent action and campaigns by external actors.

A strong example of these problematic aspects of the peace studies field is provided in relation to the West AsiaNorth Africa region and the 2010/11 WANA revolutions, with direct relevance to RtoP and RtoA. My own research 
has confirmed some of these Eurocentric, patronising and orientalising features in relation to the region and recent revolutions, characterising not just peace research but common political research paradigms such as that of authoritarianism and democratisation (Brown, 2019: 26-30). Coupled with the inclination to mitigate risk, this necessarily builds an interventionist inclination towards the region's politics, or indeed external support for 'stability' in authoritarian regimes, both of which suffocate the right to rebel. RtoP has been invoked in relation to nonviolent campaigns and actions in the region, including by the prominent Bahraini activist al-Khawaja (2014; see also Bellal \& Doswald-Beck, 2011: 8). If RtoA provides a nonviolent alternative to military intervention in this regard, it seems RtoP's existing issues concerning violent conflicts are no less applicable to nonviolent conflict. RtoA would likely run up against intervention selectiveness or 'disinterest' according to major powers' concerns, rather than multilateralism, which was made abundantly clear through NATO's military intervention in Libya, nonintervention against Syria's Al-Assad and muted response to the Gulf Cooperation Council's intervention to support the Bahrain regime. Thus, encouraging nonviolence externally on the promise of assistance seems practically dubious, rather than being a constructive and emancipatory nonviolence developed as a bottom-up process.

\section{Civil Resistance and Civilian Resistance}

A further issue of relevance to RtoP and RtoA in the context of nonviolent civil resistance is its conflation with the concept of 'civilian'. In UN documents RtoP is not narrowly referred to in relation to civilians; rather, it is referred to in relation to 'populations': "Each individual State has the responsibility to protect its populations from genocide, war crimes, ethnic cleansing and crimes against humanity" (United Nations General Assembly, 2005: 30). This is crucial in the intention of leaving no individual or group as somehow a permissible target for atrocity crimes. It evokes the Red Cross commentary on the Geneva Conventions in the wake of transgressions during the 'War on Ter- 


\section{European Human}

ror', which is explicit: "no possible loophole is left; there can be no excuse, no attenuating circumstances"' (International Committee of the Red Cross, 2005). Indeed, the context of the War on Terror is important given the USA's blatant efforts to create a third category of 'unlawful combatant' outside of IHL protections or IHRL.

Taking torture in particular in relation to US administrations' actions during the War onTerror,Waldron argued the torture prohibition to be the archetype of a policy ensuring that law is neither brutal nor savage, its removal possibly having a domino effect in demolishing prohibitions against 'lesser' offences (2005: 1726, 1729, 1735). Putting aside a question that even Clausewitz (1873) raised over whether one can realistically legislate away the brutality of war, given that war's true nature is an escalation to the extremities of violence in seeking the ultimate destruction of one's opponent, this 'slippery slope' may have been exacerbated by US actions, eroding the status of civilians and 'protected individuals' and combatants alike. The global War on Terror has exacerbated an evermore absurd (mis)application of the terms 'terrorist' and 'terrorism' by an increasing number of states to a growing array of opposition actors and their activities, based on the perception of the violence such a definition is perceived to justify. Thus, in 2011 Ben Ali, Gaddafi and Assad labelled protesters as terrorists even prior to the latter two revolutions' militarisation (Schraeder \& Redissi, 2011: 7), attempting to justify 'exceptional' human rights' infringements to an external audience. At least in the instances of Tunisia and Libya, Ben Ali and Gaddafi came to be seen as 'friends' in the War on Terror; thus, the concept offered an evermore absurd and facile international mask for oppression (Bellamy, 2006: 124, 139; Foot, 2006: 139).

Evidently, states including the USA have committed war crimes and human rights violations prior to the global War on Terror (McCoy, 2006: 108, 112) and the USA's efforts to create a status of individuals outside of legal protection, while leaders such as Ben Ali, Gaddafi and Assad hardly needed such an enabling environment to engage in such violations. Rather infamously, Colonel 
Lawrence Wilkerson of the US State Department stated: "There's an aphorism in the CIA, that if you want good intelligence, send him to Syria, if you want him to disappear, send him to Cairo. [Morocco for] a little torture [...] fingernails pulled out [...] cigarette burn on the face" (Taylor, 2011; McCoy 2006: 117). Nevertheless, broad designations under 'terrorism' and 'terrorist' in the postSeptember $11^{\text {th }}, 2001$ world have led to obfuscation of the 23 I Page boundaries of perceived permissible action under IHL.

The crucial point here is that defining individuals or groups as terrorists has become a potent (and absurd) means of justifying violent suppression, including outside of IHL or IHRL norms and including targeting of nonviolent actors and civilian populations. Concurrently, there has been some conflation of the term 'civilian' with those engaging in civil resistance (see Stephan, 2009a). For example, in order to qualify in the NAVCO analysis as a "nonviolent episode" or campaign it "must have been prosecuted by unarmed civilians who did not directly threaten or harm the physical well-being of their opponent" (Chenoweth and Lewis, 2013: 418; Chenoweth \& Cunningham, 2013: 271; Chenoweth and Ulfelder, 2015: 13). In the context of the $2010 / 11$ WANA revolutions and the instances of the 'terrorist' label's application noted above, it was opposition broadly adopting civil resistance (at least initially) who were being denounced as such. This exemplifies that nonviolent resistance and resisters are not immune from practically baseless yet symbolically loaded designation.

In this WANA context, one should consider the phrase 'Civilian Jihad', adopted by Stephan (2009a) from Khalid Kishtainy (2002) to "describe a form of political struggle whose "weapons" include boycotts, strikes, protests, sitdowns, humour, and other acts of civil disobediences and non-violent defiance" (Stephen, 2009a: 1). Kishtainy's (2002) arguments for the term's adoption are superficially convincing, having explained the intention of rescuing jihad from its violent associations, while attempting to encourage nonviolence's appeal to an Arab audience (also Stephan, 2009a: 6, 11). Nevertheless, this aim would be more effectively fulfilled by extending familiarity with 


\section{European Human \\ Journal of Security}

Page I 24

appropriate definition, understanding and awareness of the concept of jihad $a b$ intra, rather than prefixing the term with a word inferring nonviolence (see SathaAnand, 1993; Mohideen, 1993; Abu-Nimer, 2015: 41).

Thus, one wonders whether this terminology falls in to the common external perceptions of the region, where adopting 'civilian jihad' is actually as much for external audiences and forces as it is for indigenous audiences to learn about alternatives to violence. Stephan's volume itself indicated that there is hardly a need for resistance movements, well-established in using nonviolence, to learn about its utility. Thus the supposed monopoly of jihadist forces on militancy is an assumption itself. While 'civil' in relation to civil resistance has rather been determined as relating to "a citizen or society, implying that a movement's goals are 'civil' in the sense of being widely shared in a society", with actions being "nonmilitary or non-violent in character" (Roberts, 2009: 2; Hallward \& Norman, 2015a: 7), Stephan gave a definition of civil resistance as "Widespread and sustained activities by ordinary civilians against a particular power, force, policy or regime" (2009a: 1). It is not convincing why this and various commonly used nonviolent terminology cannot simply be applied to the WANA region, rather than risking a further entrenchment of Middle East exceptionalism. There is of course a chance that this emphasis on civilians undertaking nonviolent action is a further justification for 'protection', intervention and 'assistance' in the region. Essentially, conflating the status of civilian with civil resistance risks further undermining civilian neutrality under international law, rather than absolving participants in nonviolent actions of a state or regime's violent excesses in response.

While the connection of civilians to nonviolence likely stems from the latter concept's association with governed citizens' withdrawal of consent (Gandhi, 1961: 7; Sharp, 2010: 31), a regime's legitimacy often remains ambiguous. Much of this ambiguity rests on external perceptions and factors, one might say realpolitik, which potentially has a crucial influence on nonviolent campaigns (Davies, 2014: 302). Thus, considering the 


\section{European Human \\ Journal of Security}

previous support given to authoritarian regimes by major powers, which has proven a considerable hindrance to grassroots movements (Zunes \& Ibrahim, 2009: 95; Zunes, 2011: 403), would be more meaningful. If analysts of nonviolence are increasingly showing its effectiveness through quantitative analysis, that others are advocating intervention that may only regulate or control indigenous and grassroots campaigns is highly questionable.

\section{Conclusion}

In emphasising the prevention measures that are an aspect of RtoP, RtoA focuses on an area of positive and crucial activity, averting those actions that reflect the worst of humanity, and indeed seeking an end to violence more broadly. While of worthy intent, it is difficult to see what RtoA fundamentally adds to nonviolent action and more generally the 'just' waging of conflict. Bottom-up, indigenous nonviolent resistance has been and is pursued worldwide irrespective of its legal permissibility within a state-this is inherent in civil disobedience-and assistance has been offered by an array of external actors in certain conflicts irrespective of its legality in the 'donor' or recipient state. S6,+omehow enshrining this broad spectrum of morally permissible actions to assist within a legal protection risks legally defining and restricting what is and is not permissible under one's right to resist, irrespective of circumstances. Whether intentionally or otherwise, this can also channel what forms of resistance actors pursue in order to receive official assistance from civil society, the state or international organisations.

Thus, this may compound the problem whereby, as in the case of Bahrain and the appeal of Al-Khawaja (2014), activists believe they can tick the box of nonviolence and then lobby for international intervention or assistance as a rapid and swift resolution to their regime issue. Bahrain is a highly pertinent example; in the current international system, the right to assist the Bahraini opposition in 2011 would have been extremely unlikely (then or in other cases in future) to have been deferred to over 


\section{European Human \\ Journal of Security}

dominant external state powers' preference for stability. Any expectation of help upon adherence to nonviolent discipline simply to trigger a formalised right to assist (or protect) is naïve and liable to leave a campaign high and dry; in a context such as Bahrain, this can make external calls for nonviolent discipline dangerously misleading (Sørensen, 2017: 132) when not grounded in understanding of the context of action (Vinthagen, 2015a: 91; Baaz et al., 2018: 11, 13).

It is important to emphasise that in many instances, a nonviolent civil resistance campaign would be far better off pursuing a strategy and tactics reflective of the specific context. The risk of a descent into brutal violence and perhaps even atrocity crimes on both sides is possible even from an initially nonviolent campaign, as the Syrian revolution since 2011 indicates. In fulfilling the broader context of RtoP in terms of human security-which the UN itself acknowledges falls on every individual as well as the collective-nonviolent resistance inherently reflects diversity, pluralism and dignity when being both without violence and against violence (Vinthagen, 2015a: 218), both born of and reflective of the specific context and circumstances of action. Despite the rhetoric of RtoA seeming to acknowledge as much (Ackerman \& Merriman, 2019), its inherent and strict characteristics seem to pose too great a challenge of contrary, disciplining and potentially dangerous outcomes for resistance campaigns. Mindful of the suggestion in this journal that "the contemporary model of human security needs to be reconstructed as a strategy of resistance" (Martin, 2017: 24; Chinkin \& Kaldor, 2017), respect and support from external actors for bottom-up efforts at pursuing human security should continue with broadly informal acts of solidarity. One crucial effort in that regard would be external assisters' acknowledgement and resistance against structural violence 'at home', pressuring their governments not to openly or tacitly support authoritarian regimes. 


\section{REFERENCES}

Abu-Nimer, M. (2015). Spiritual and Religious approaches to nonviolence. In M. C. Hallward \& M. J. Norman (Eds.), Understanding nonviolence (pp. 39-61). Cambridge: Polity Press.

Ackerman, P., \& Kruegler, C. (1994). Strategic Nonviolent Conflict: The Dynamics of People Power in the Twentieth Century. Westport, Connecticut; London: Praeger.

Ackerman, P., \& Rodal, B. (2008). The Strategic Dimensions of Civil Resistance. Survival: Global Politics and Strategy, 50(3), 111-126.

Ackerman, P., \& Merriman, H. (2019). Preventing Mass Atrocities: From a Responsibility to Protect (RtoP) to a Right to Assist (RtoA) Campaigns of Civil Resistance (Vol. 3). Chicago: ICNC.

Al-Khawaja, M. (2014). Crackdown: The Harsh Realities of Nonviolent Protests in the Bahraini Civil Conflict. Journal of International Affairs, 68(1), 189-200.

Asal, V., Legault, R., Szekely, O., \& Wilkenfeld, J. (2013). Gender Ideologies and Forms of Contentious Mobilisation in the Middle East. Journal of Peace Research, 50(3), 305-318.

Baaz, M., Lilja, M., \& Vinthagen, S. (2018). Researching Resistance and Social Change: A Critical Approach to Theory and Practice. London; New York: Rowman \& Littlefield.

Bamyeh, M. (2012). The Tunisian Revolution: Initial Reflections. In B. Haddad, R. Bsheer \& Z. Abu-Rish (Eds.), The Dawn of the Arab Uprisings: End of an Old Order? (pp. 49-58). London: Pluto.

Bartkowski, M. J. (2015). Revolutions and Democratic Transitions. In M. C. Hallward \& M. J. Norman (Eds.), Understanding Nonviolence (pp. 148-170). Cambridge: Polity Press.

Bauman, Z. (1997). Postmodernity and its Discontents. Cambridge: Polity Press.

Bayer, M., Bethke, F. S., \& Lambach, D. (2016). The Democratic Dividend of Nonviolent Resistance. Journal of Peace Research, 53(6), 758-771. 


\section{European Human}

Beck, U. (1992). Risk Society: Towards a New Modernity. London: Sage Publications.

Bellal, A., \& Doswald-Beck, L. (2011). Evaluating the Use of Force During the Arab Spring. In M. N. Schmitt \& L Arimatsu (Eds.), Yearbook of International Humanitarian Law: Volume 14 (pp. 3-35). The Hague: Asser Press.

Bellamy, A. J. (2006). No pain, no gain? Torture and ethics in the war on terror. International Affairs, 82(1), 121-148.

Basu, S. (2012). Security as Emancipation: A Feminist Perspective. In A. Tickner \& L. Sjoberg (Eds.), Feminism and International Relations: Conversations about the Past, Present and Future (pp. 98-114). London: Routledge.

Bilgic, A. (2015). Real People in Real Places: Conceptualising Power for Emancipatory Security through Tahrir. Security Dialogue, 46(3), 272-290.

Boesak, A. A. (2011). For the Tyrant Shall Be No More: Reflections On and Lessons from 'The Arab Spring' in North Africa, the Middle East and the Civil Rights and Anti-Apartheid Struggles. Theological Studies, 67(3), 1-9

Brown, C. S. (2016). Framing the 'Arab Spring': Orientalism and the British media. Revue Mawarid. Special Issue, 27-58.

Brown, C. S. (2018). 'Riots' during the 2010/11 Tunisian Revolution: A Response to Case's Article in JRS Vol.4 Issue 1. Journal of Resistance Studies, 4(2), 112-131.

Brown, C. S. (2019). (Non)violent Revolution: Origins, Theory and Practice during the 2010/11 Revolution (Doctoral dissertation). Leeds: Leeds Beckett University.

Butcher, C., \& Svensson, I. (2016). Manufacturing Dissent: Modernisation and the Onset of Major Nonviolent Resistance Campaigns. Journal of Conflict Resolution, $60(2), 311-339$.

Case, B. S. (2018). Riots as Civil Resistance: Rethinking the Dynamics of 'Nonviolent' Struggle. Journal of Resistance Studies, 4(1), 9-44.

Chabot, S. \& Vinthagen, S. (2007). Rethinking Nonviolent Action and Contentious Politics: Political Cultures of Nonviolent Opposition in the Indian Independence Movement and Brazil's Landless Workers Movement. Research in Social Movements, Conflicts and Change, 27, 91-121. 


\section{European Human}

Chabot, S., \& Sharifi, M. (2013). The Violence of Nonviolence: Problematising Nonviolent Resistance in Iran and Egypt. Societies Without Borders, 8(2), 1-27.

Chenoweth, E., \& Stephan, M. J. (2011). Why Civil Resistance Works: The Strategic Logic of Nonviolent Conflict. New York: Columbia University Press.

Chenoweth, E., \& Cunningham, K. G. (2013). Understanding Nonviolent Resistance: An Introduction. Journal of Peace Research, 50(3), 271-276.

Chenoweth, E., \& Lewis, O. A. (2013). Unpacking nonviolent campaigns: Introducing the NAVCO 2.0 dataset. Journal of Peace Research, 50(3), 415-423.

Chenoweth, E., \& Schock, K. (2015). Do Contemporaneous Armed Challenges Affect the Outcomes of Mass Nonviolent Campaigns? Mobilization: An International Quarterly, 2(4), 427-451.

Chenoweth, E., \& Ulfelder, J. (2015). Can Structural Conditions Explain the Onset of Nonviolent Uprisings? Journal of Conflict Resolution, 61(2), 1-27.

Chinkin, C., \& Kaldor, M. (2017). International law and new wars. University of Cambridge: Cambridge University Press.

Clark, H. (2009). Introduction. In H. Clark (ed.), People Power: Unarmed Resistance and Global Solidarity (pp. 1-20). London; New York: Pluto Press.

Cunningham, K. G. (2013). Understanding Strategic Choice: The Determinants of Civil War and Nonviolent Campaign in Self-Determination Disputes. Journal of Peace Research, 50(3), 291-304.

Davies, R. T. (2014). The Failure of Strategic Nonviolent Action in Bahrain, Egypt, Libya and Syria: 'Political Ju-Jitsu' in Reverse. Global Change, Peace \& Security, 26(3), 299-313.

Dudouet, V. (2015). Sources, Functions, and Dilemmas of External Assistance to Civil Resistance Movements. In K. Schock (Ed.), Civil Resistance: Comparative Perspectives on Nonviolent Struggle (pp. 168-199). Minneapolis; London: University of Minnesota Press.

Duffield, M. (2007). Development, Security and Unending War: Governing the World of Peoples. Cambridge: Polity Press.

Ettang, D. (2014). Factors for Successful Nonviolent Action in Africa. Peace Review: A Journal of Social Justice, 26(3), 412-419. 


\section{European Human \\ Journal of Security}

Foot, R. (2006). Torture: the struggle over a peremptory norm in a counter-terrorist era. International Relations, 20(2), 131-152.

Galtung, J. (1969). Violence, peace, and peace research. Journal of peace research, 6(3), 167-191.

Galtung, J. (1990). Cultural violence. Journal of peace research, 27(3), 291-305.

Gandhi, M. K. (1961). Non-violent Resistance. New York: Schocken Books.

Garton Ash, T. G. (2009). A Century of Civil Resistance: Some Lessons and Questions. In A. Roberts \& T. Garton Ash (Eds.), Civil Resistance \& Power Politics: The Experience of Non-violent Action from Gandhi to the Present (pp. 371-391). Oxford: Oxford University Press.

Gleditsch, N. P., Nordås, R., \& Urdal, H. (2017). Peer Review and Replication Data: Best Practice from Journal of Peace Research. College \& Research Libraries, March, 267-271.

Hallward, M. C., \& Norman, M. J. (2015a). Introduction. In M. C. Hallward \& M. J. Norman (Eds.), Understanding Nonviolence (pp. 3-13). Cambridge: Polity Press.

Hallward, M. C. \& Norman, J. M. (2015b). Understanding Nonviolence. In M. C. Hallward \& M. J. Norman (eds.), Understanding Nonviolence (pp. 14-35). Cambridge: Polity Press.

Hegre, H., Metternich, N. W., Nygard, H. M., \& Wucherpfennig, J. (2017). Introduction: Forecasting in Peace Research. Journal of Peace Research, 54(2), 113-124.

Honwana, A. (2013). Youth and Revolution in Tunisia. London; New York: Zed Books.

Hoynes, W. (2014). Assessing Nonviolent Movements. Peace Review: A Journal of Social Justice, 26(1), 1-3.

International Commission on Intervention and State Sovereignty. (2001). The Responsibility to Protect. Ottawa, ON: International Development Research Centre.

International Committee of the Red Cross [ICRC]. (2005). Geneva Convention Commentary, Part I: General provisions. Article 3 ' Sub-paragraphs (1) and (2) -Extent of the obligation'. Retrieved from: http://www. icrc.org/ihl.nsf/com/375-590006?OpenDocument

International Covenant on Civil and Political Rights. (1966). Vol.999, No. 14668. New York: United Nations. Retrieved from: https://treaties.un.org/doc/publica- 


\section{European Human}

tion/unts/volume\%20999/volume-999-i-14668-english.pdf

Jackson, R. (2015). How Resistance Can Save Peace Studies. Journal of Resistance Studies, 1(1), 18-49.

Johansen, J. (2009). External Financing of Opposition Movements. In H. Clark (ed.), People Power: Unarmed Resistance and Global Solidarity (pp. 198-205). London; New York: Pluto Press.

Julian, R., \& Schweitzer, C. (2015). The Origins and Development of Unarmed Civilian Peacekeeping. Peace Review: A Journal of Social Justice, 27(1), 1-8.

Khatib, L., \& Lust, E. (2014). Taking to the Streets: The Transformation of Arab Activism. Baltimore: John Hopkins University Press.

King, M. (2009). Palestinian Civil Resistance against Israeli Miitary Occupation. In M. J. Stephan (ed.), Civilian Jihad: Nonviolent Struggle, Democratisations, and Governance in the Middle East (pp. 131-156). New York: Palgrave Macmillan.

Kishtainy, K. (2002). Nonviolence and "Civilian Jihad". Retrieved from: http://www.commongroundnews. org/article.php?id=21078\&lan=en\&sp=1

Koren, O. (2014). Military Structure, Civil Disobedience, and Military Violence. Terrorism and Political Violence, 26(4), 688-712.

Lehoucq, F. (2016). Review: Does Nonviolence Work? Comparative Politics, 48(2), 269-287.

Martin, M. (2017). Human Security: Present and Future Frontiers. European Journal of Human Security, (1), 9-26.

McCoy, A. N. (2006). A question of torture: CIA interrogation, from the Cold War to the War on Terror. New York: Metropolitan Books.

Mohideen, M. M. (1993). Islam, Nonviolence and Interfaith Relations. In G. D. Paige, C. Satha-Anand \& S. Gilliatt (Eds.), Islam and Nonviolence (pp. 123-144). Honolulu, Hawai'i: Center for Global Nonviolence Planning Project.

Naess, A. (1974). Gandhi and Group conflict: An Exploration of Satyagraha. Oslo; Bergen; Tromso: Universitetsforlaget.

Nepstad, S. E. (2011). Nonviolent Resistance in the Arab Spring: The Critical Role of Military-Opposition Alliances. Swiss Political Science Review, 17(4), 485-491. 


\section{European Human \\ Journal of Security}

Nepstad, S. E. (2013). Nonviolent Civil Resistance and Social Movements. Sociology Compass, 7, 590-598.

Norman, J. M. (2015). “We Do Not Work for Peace”: Reframing Nonviolence in Post-Oslo Palestine. In K. Schock, (ed.), Civil Resistance: Comparative Perspectives on Nonviolent Struggle (pp. 35-58). Minneapolis; London: University of Minnesota Press.

Page I 32 Pearlman, W. (2011). Violence, Nonviolence, and the Palestinian National Movement. New York: Cambridge University Press.

Patomäki, H. (1997). The Rhetorical Strategies and the Misleading Nature of Attacks on Postmodernism: A Reply to Østerud. Journal of Peace Research, 34(3), 325-329.

Patomäki, H. (2001). The challenge of critical theories: peace research at the start of the new century. Journal of Peace Research, 38(6), 723-737.

Reed, J-P. \& Foran, J. (2002). Political Cultures of Opposition: Exploring Idioms, Ideologies, and Revolutionary Agency in the Case of Nicaragua. Critical Sociology, 28 (3), 335-370.

Roberts, A. (2009). Introduction. In A. Roberts \& T. Garton Ash (Eds.), Civil Resistance \& Power Politics: The Experience of Non-violent Action from Gandhi to the Present (pp. 1-24). Oxford: Oxford University Press.

Rogers, P., \& Ramsbotham, O. (1999). Then and Now: Peace Research- Past and Future. Political Studies, 47, 740754.

Satha-Anand, C. (1993). Introduction. In G. D. Paige, C. SathaAnand \& S. Gilliatt (Eds.), Islam and Nonviolence (pp. 1-6). Honolulu, Hawai'i: Center for Global Nonviolence Planning Project.

Schock, K. (2005). Unarmed Insurrections: People Power Movements in Nondemocracies. Minneapolis, MN: University of Minnesota Press.

Schock, K. (2013). The Practice and Study of Civil Resistance. Journal of Peace Research, 50(3), 277-290.

Schock, K. (2015a). Introduction: Civil Resistance in Comparative Perspective. In K. Schock (ed.), Civil Resistance: Comparative Perspectives on Nonviolent Struggle (pp. 1-32). Minneapolis; London: University of Minnesota Press.

Schock, K. (2015b). Civil Resistance in the Twenty-First Century. In K. Schock (ed.), Civil Resistance: Comparative 


\section{European Human}

Perspectives on Nonviolent Struggle (pp. 302-317). Minneapolis; London: University of Minnesota Press.

Schraeder, P., \& Redissi, H. (2011). The Upheavals in Egypt and Tunisia: Ben Ali's Fall. Journal of Democracy, 22(3), 5-19.

Sémelin, J., Andrieu, C. \& Gensburger, S. (Eds.) (2011). Resisting genocide: The multiple forms of rescue. New York: Columbia University Press.

Sharp, G. (1973). The Politics of Nonviolent Action. Boston, MA: Porter Sargent Publisher.

Sharp, G. (2010). From Dictatorship to Democracy: A Conceptual Framework for Liberation ( $4^{\text {th }}$ ed.). East Boston, MA: The Albert Einstein Institution.

Shaykhutdinov, R. (2010). Give Peace a Chance: Nonviolent Protest and the Creation of Territorial Autonomy Arrangements. Journal of Peace Research, 47(2), 179-191.

Sørensen, M. J. (2016). Constructive Resistance: Conceptualising and Mapping the Terrain. Journal of Resistance Studies, 2(1), 49-78.

Sørensen, M. J., \& Johansen, J. (2016). Nonviolent Conflict Escalation. Conflict Resolution Quarterly, 34(1), 83-108.

Sørensen, M. J. (2017). Glorifications and Simplifications in Case Studies of Danish WWII Nonviolent Resistance. Journal of Resistance Studies, 3(1), 99-137.

Stephan, M. (Ed.). (2009a). Civilian Jihad: Nonviolent Struggle, Democratization, and Governance in the Middle East. Basingstoke: Palgrave Macmillan.

Stephan, M. J. (2009b). Conclusion. In: M. J. Stephan (ed.), Civilian Jihad: Nonviolent Struggle, Democratisations, and Governance in the Middle East (pp. 301-315). New York: Palgrave Macmillan.

Stephan, M. J., \& Chenoweth, E. (2008). Why Civil Resistance Works: The Strategic Logic of Nonviolent Conflict. International Security, 33(1), 7-44.

Stephan, M. J., Lakhani, S., \& Naviwala, N. (2015). Aid to Civil Society: A Movement Mindset (Special Report 361). Washington, D.C: United States Institute of Peace.

Sutton, J., Butcher, C. R., \& Svensson, I. (2014). Explaining Political Jiu-Jitsu: Institution Building and the Outcomes of Regime Violence against Unarmed Protests. Journal of Peace Research, 51(5), 559-573. 


\section{European Human \\ Journal of Security}

Svensson, I., \& Lindgren, M. (2010). Community and consent: Unarmed insurrections in nondemocracies. European Journal of International Relations, 17(1), 97-120.

Svensson, I., \& Lindgren, M. (2011). From bombs to banners? The decline of wars and the rise of unarmed uprisings in East Asia. Security Dialogue, 42(3), 219-237.

Taylor, P. (Director). (2011, March 14). The Secret War on Terror [Documentary]. London, UK: BBC Two.

United Nations General Assembly. (2005). Resolution adopted by the General Assembly on 16 September 2005. A/RES/60/1. (24 $4^{\text {th }}$ October). Retrieved from: https://undocs.org/en/A/RES/60/1

United Nations General Assembly. (2009). Implementing the Responsibility to Protect: Report of the SecretaryGeneral. New York: United Nations. A/63/677. (12 $2^{\text {th }}$ January). Retrieved from: https://undocs.org/ en/A/63/677

United Nations General Assembly \& United Nations Security Council. (2011). The Role of Regional and Subregional Arrangements in Implementing the Responsibility to Protect: Report of the Secretary-General. New York: United Nations. A/65/877-S/2011/393. (13 ${ }^{\text {th }}$ July 2011). Retrieved from: https://undocs.org/ en/A/65/877

United Nations General Assembly \& United Nations Security Council. (2012). Responsibility to Protect: Timely and Decisive Response: Report of the Secretary General. A/66/874-S/2012/578. (25 th July 2012). Retrieved from: https://undocs.org/en/A/66/874

United Nations General Assembly \& United Nations Security Council. (2013). Responsibility to Protect: State Responsibility and Prevention. Report of the SecretaryGeneral. A/67/929-S/2013/399. (9 ${ }^{\text {th }}$ July 2013). Retrieved from: https://undocs.org/en/A/67/929

United Nations General Assembly \& United Nations Security Council. (2015). Comprehensive Review of the Whole Question of Peacekeeping Operations in all their Aspects: Identical Letters dated 17 June 2015 from the SecretaryGeneral Addressed to the President of the General Assembly and the President of the Security Council. A/70/95-S/2015/446. (17 th June 2015). Retrieved from: https://undocs.org/en/A/70/95

United States Holocaust Memorial Museum. (2019a). The Nuremberg Race Laws. Retrieved from: https:// 


\section{European Human}

encyclopedia.ushmm.org/content/en/article/thenuremberg-race-laws

United States Holocaust Memorial Museum. (2019b). Rescue and Resistance. Retrieved from: https:// encyclopedia.ushmm.org/content/en/article/ rescue-and-resistance?parent=en $\% 2 \mathrm{~F} 11170$

Vinthagen, S. (2015a). A Theory of Nonviolent Action: How Civil Resistance Works. London: Zed Books.

Vinthagen, S. (2015b). Four Dimensions of Nonviolent Action: A Sociological Perspective. In K. Schock (ed.), Civil Resistance: Comparative Perspectives on Nonviolent Struggle (pp. 258-288). Minneapolis; London: University of Minnesota Press.

Vinthagen, S. (2015c). An Invitation to Develop "Resistance Studies". Journal of Resistance Studies, 1(1), 5-11.

von Clausewitz, C. (1873). What is War. On War. Retrieved from: http://www.clausewitz.com/readings/ OnWar1873/TOC.html

Waldron, J. (2005). Torture and positive law: jurisprudence for the White House. Columbia Law Review, 105(6), 1681-1750.

War Resisters' International. (2017). Conflict. Empowering Nonviolence. Retrieved from: https://www. nonviolence.wri-irg.org/en/node/40498

Zunes, S., \& Ibrahim, S. E. (2009). External Actors and Nonviolent Struggles in the Middle East. In M. J. Stephan (ed.), Civilian Jihad: Nonviolent Struggle, Democratisations, and Governance in the Middle East (pp. 91-105). New York: Palgrave Macmillan.

Zunes, S. (2011). Nonviolent Revolution in the Middle East. Peace Review: A Journal of Social Justice, 23(3), 396403. 